\title{
Simplified indexes for the seismic vulnerability of ancient masonry buildings
}

P.B. Lourenço ${ }^{1}$ and J.A. Roque ${ }^{2}$

\section{Abstract}

This paper presents a contribution for the safety assessment of historical masonry buildings under seismic loading. Three different simplified safety indexes (in-plan area ratio, area to weight ratio and base shear ratio) are analyzed, taking into account a large sample of fifty-eight Portuguese churches. The sample of building has been organized according to the seismic zonation, from high to low seismicity. The results indicate that valuable information can be obtained from simplified methods, with respect to performing a first screening and to prioritizing further, deeper investigations. A new proposal is made regarding the combined usage of two of the indexes.

\section{Keywords:}

Masonry; Ancient buildings; Churches; Simplified methods; Seismic vulnerability

\section{Introduction}

Ancient masonry structures are particularly vulnerable to dynamic actions, with a special focus on seismic action. Countries from the Mediterranean basin are particularly at risk due to the large number of ancient monuments and dwellings. Due to the ageing process as well as to the environmental factors, many cultural heritage buildings, as structures planned and constructed in the past, result to be vulnerable to dynamic loads, which may unpredictably induce a collapse of a portion or drive the whole structure to a rapid failure. But the high vulnerability of historical masonry buildings to seismic actions is mostly due to the absence of adequate

\footnotetext{
${ }^{1}$ Associate Professor of Civil Engineering, University of Minho, Azurém, P - 4800-058 Guimarães, Portugal, Tel+351510 200, Fax+351253 510217, E-mail pbl@civil.uminho.pt

${ }^{2} \mathrm{PhD}$ Student, University of Minho. Lecturer at Polytechnic Institute of Bragança.
} 
connections between the various parts (masonry walls, timber beams in the floors and timber beams in the roof). This characteristic leads to overturning collapse of the perimeter walls under seismic horizontal acceleration.

An analysis of the damage survey of historical masonry buildings for the Umbria-Marche earthquake [1] shows that the problem is generalized and that structural typologies, as well as associated type and distribution of damage, are fairly recurring. Vulnerability may be reduced through retrofitting/protection to better resist the seismic demand. Anti-seismic action requires the knowledge of seismic site response, the definition of the seismic load (a rather challenging issue) and the knowledge of the characteristics of existing buildings. This is a gigantic task, requiring large funds and considerable large time-span, but several efforts have been made to create damage scenarios and to prioritize retrofitting works, e.g. [2,3].

The approach sought here is much more simple, fast and low cost, being based on a simplified geometric approach for immediate screening of the large number of buildings at risk. The objective is to detect historical buildings at possible risk for subsequent more detailed study using advanced computer simulations, together with adequate material and structural characterization, see $[4,5]$ for recommendations. In case of urban areas, and in spite of the diversity, a common matrix can usually be established for the seismic areas, more structural than technological. This consists of low building height (up to three stories), moderate spans (maximum of four or five meters) and large thickness of the walls (less than 1/7 of the height) [6].

The paper concentrates in churches, given: (a) their intrinsic greater structural vulnerability due to open plan, greater height to width ratio and, often, the presence of thrusting horizontal structures from vaulted ceilings and timber roof; (b) the ample geometry survey drawings and documentation available. Moreover, in earthquake prone countries, churches have already been subjected to earthquakes, and sometimes survived them, meaning that they are testimonies and they represent full-scale testing data. This fact, permits to discuss and, generally, to accept that these ancient structures have been adjusted to local seismicity.

Fifty-eight Portuguese churches have been selected and analyzed with three simplified expedite methods, namely in-plan area ratio, area to weight ratio and base shear ratio. The churches are located in different seismic zones aiming at verifying the likely existence of a correlation between structural characteristics and seismic zone.

\section{Simplified Methods of Analysis}

The analysis of historical masonry constructions is a complex task, namely because: (a) geometry data is missing; (b) information about the inner core of the structural elements is also missing; (c) characterization of 
the mechanical properties of the materials used is difficult and expensive; (d) large variability of mechanical properties, due to workmanship and use of natural materials; (e) significant changes in the core and constitution of structural elements, associated with long construction periods; (f) construction sequence is unknown; (g) existing damage in the structure is unknown; (h) regulations and codes are non-applicable. Moreover, the behavior of the connections between masonry elements (walls, arches and vaults) and masonry elements and timber elements (roofs and floors) is usually unknown. All these factors, indicate that the quantitative results of structural analysis must be looked at with reserves, in the case of vertical loading and, even more carefully, in the case of seismic action. Therefore, more complex and accurate methods do not correspond necessarily to more reliable and better analyses.

The usage of simplified methods of analysis usually requires that the structure is regular and symmetric, that the floors act as rigid diaphragms and that the dominant collapse mode is in plane shear failure of the walls [7]. In general, these last two conditions are not verified by ancient masonry structures, meaning that simplified methods should not be understood as quantitative safety assessment but merely as a simple indicator of possible seismic performance of a building. Here, the following simplified methods of analysis and corresponding indexes are considered:

- Index 1: In-plan area ratio;

- Index 2: Area to weight ratio;

- Index 3: Base shear ratio.

These methods can be considered as an operator that manipulates the geometric values of the structural walls and produces a scalar. As the methods measure different quantities, their application to a large sample of buildings contributes to further enlightening of their application. As stated above, a more rigorous assessment of the actual safety conditions of a building is necessary to have quantitative values and to define remedial measures, if necessary.

\subsection{Index 1: In-plan area ratio}

The simplest index to assess the safety of ancient constructions is the ratio between the area of the earthquake resistant walls in each main direction (transversal $x$ and longitudinal $y$, with respect to the church nave) and the total in-plan area of the buildings. According to Eurocode 8 [8], walls should only be considered as earthquake resistant if the thickness is larger than $0.35 \mathrm{~m}$, and the ratio between height and thickness is smaller than nine. The first index $\gamma_{1, i}$ reads: 


$$
\gamma_{1, i}=A_{w i} / S \quad[-]
$$

where $A_{w i}$ is the in plan area of earthquake resistant walls in direction " $i$ " and $S$ is the total in plan area of the building.

The non-dimensional index $\gamma_{1, i}$ is the simplest one, being associated with the base shear strength. Special attention is required when using this index as it ignores the slenderness ratio of the walls and the mass of the construction. Eurocode 8 [8] recommends values up to $5-6 \%$ for regular structures with rigid floor diaphragms. In cases of high seismicity, a minimum value of $10 \%$ seems to be recommended for historical masonry buildings [7]. For simplicity sake, high seismicity cases can be assumed as those where the design ground acceleration for rock-like soils is larger than $0.2 \mathrm{~g}$.

\subsection{Index 2: Area to weight ratio}

This index provides the ratio between the in plan area of the earthquake resistant walls in each main direction (again, transversal $x$ and longitudinal $y$ ) and the total weight of the construction, reading:

$$
\gamma_{2, i}=A_{w i} / G \quad\left[\mathrm{~L}^{2} \mathrm{~F}^{-1}\right]
$$

where $A_{w i}$ is the in plan area of earthquake resistant walls in direction " $i$ " and $G$ is the quasi-permanent vertical action.

This index is associated with the horizontal cross-section of the building, per unit of weight. Therefore, the height (i.e the mass) of the building is taken into account, but a major disadvantage is that the index is not non-dimensional, meaning that it must be analyzed for fixed units. In cases of high seismicity, a minimum value of $1.2 \mathrm{~m}^{2} / \mathrm{MN}$ seems to be recommended for historical masonry buildings [7].

\subsection{Index 3: Base shear ratio}

Finally, the base shear ratio provides a safety value with respect to the shear safety of the construction. The total base shear for seismic loading $\left(V_{S d, b a s e}=F_{E}\right)$ can be estimated from an analysis with horizontal static loading equivalent to the seismic action $\left(F_{E}=\beta \times G\right)$, where $\beta$ is an equivalent seismic static coefficient related to the design ground acceleration. The shear strength of the structure $\left(V_{R d, b a s e}=F_{R d}\right)$ can be estimated from the 
contribution of all earthquake resistant walls $F_{R d, i}=\sum A_{w i} \times f_{v k}$, where, according to Eurocode 6 [9], $f_{v k}=f_{v k 0}+$ $0.4 \sigma_{d}$. Here, $f_{v k 0}$ is the cohesion, which can be assumed equal to a low value or zero in the absence of more information, $\sigma_{d}$ is the design value of the normal stress and 0.4 represents the tangent of a constant friction angle $\varphi$, equal to $22^{\circ}$.

The new index $\gamma_{3}$ reads:

$$
\gamma_{3, i}=F_{R d, i} / F_{E} \quad[-]
$$

If a zero cohesion is assumed $\left(f_{v k 0}=0\right), \gamma_{3, i}$ is independent from the building height, reading:

$$
\gamma_{3, i}=V_{R d, i} / V_{S d}=A_{w i} / A_{w} \times \tan \varphi / \beta
$$

but for a non-zero cohesion, which is most relevant for low height buildings, $\gamma_{3, i}$ reads:

$$
\gamma_{3, i}=V_{R d, i} / V_{S d}=A_{w i} / A_{w} \times\left[\tan \varphi+f_{v k 0} /(\gamma \times h)\right] / \beta
$$

where $A_{w i}$ is the in plan area of earthquake resistant walls in direction " $i$ ", $A_{w}$ is the total in plan area of earthquake resistant walls, $h$ is the (average) height of the building, $\gamma$ is the volumetric masonry weight, $\varphi$ is the friction angle of masonry walls and $\beta$ is an equivalent static seismic coefficient. Here, it is assumed that the normal stress in the walls is only due to their self-weight, i.e. $\sigma_{d}=\gamma \times h$, which is on the safe side and is a very reasonable approximation for historical masonry building, usually made of very thick walls.

Moreover, assuming a tangent of the friction angle in the range of 0.4 , a value of the cohesion $f_{v k 0}$ in the range of $0.1 \mathrm{~N} / \mathrm{mm}^{2}$, and a volumetric weight $\gamma$ equal to $20 \mathrm{kN} / \mathrm{m}^{3}\left(2 \times 10^{-5} \mathrm{~N} / \mathrm{mm}^{3}\right)$, the modified value of $\tan \varphi$ in Eq. (5) reads $\tan \varphi+f_{v k 0} /(\gamma \times h)=0.4+0.1 /\left(2 \times 10^{-5} \times h\right)$. This means that the contribution of the cohesion is very large (for a height $h$ equal to $5.0 \mathrm{~m}, \tan \varphi+f_{v k 0} /(\gamma \times h)$ equals 1.4 , for $10.0 \mathrm{~m}$, it equals 0.9 , and for $20.0 \mathrm{~m}$, it equals 0.65 ) and Eq. (5) must be used rather carefully. In the rest of this paper, zero cohesion will be assumed as a conservative value.

This non-dimensional index considers the seismicity of the zone, taken into account in $\beta$. The building will be safer with increasing ratio (earthquake resistant walls/weight), i.e. larger relation $\left(A_{w i} / A_{w}\right)$ and lower heights. For this type of buildings and action, a minimum value of $\gamma_{3, i}$ equal to one seems acceptable. 


\subsection{Preliminary Comparative Analysis}

Eqs. (1-4) can be recast in a similar format as a function of the ratio $\left(A_{w i} / A_{w}\right)$, which allows direct comparison between the different methods, as

$$
\begin{array}{ll}
\text { Index 1: } \gamma_{1, i}=A_{w i} / S=A_{w i} / A_{w} \times A_{w} / S=A_{w i} / A_{w} \times k_{1} & {\left[\mathrm{~L}^{2} / \mathrm{L}^{2}\right]} \\
\text { Index 2: } \gamma_{2, i}=A_{w i} / G=A_{w i} / A_{w} \times 1 /(\gamma \times h)=A_{w i} / A_{w} \times k_{2} & {\left[\mathrm{~L}^{2} / \mathrm{F}\right]} \\
\text { Index 3: } \gamma_{3, i}=V_{R d, i} / V_{S d}=A_{w i} / A_{w} \times \tan \varphi / \beta=A_{w i} / A_{w} \times k_{3} & {[\mathrm{~F} / \mathrm{F}]} \\
k_{1}=A_{w} / S \quad ; \quad k_{2}=1 /(\gamma \times h) \quad ; \quad k_{3}=\tan \varphi / \beta &
\end{array}
$$

Here, it is stressed that the ratio $\left(A_{w i} / A_{w}\right)$ represents the percentage of earthquake resistant walls in a given direction in relation to the total area of earthquake resistant walls in the building.

The new expressions for the scalar indexes indicate that they are all linearly dependent on the ratio $\left(A_{w i} / A_{w}\right)$. This ratio provides direct information about the in plan stiffness of the structure along each main direction and it is usually accepted that the sum of the relations $\left(A_{w i} / A_{w}\right)$ for the two orthogonal directions can be larger than the unit value, due to superposition of the areas in the two directions [7].

The indexes depend linearly also in the following quantities: (a) ratio between total area of earthquake resistant walls and total in plan area of the building (Index 1); (b) height of the building (Index 2); (c) ratio between friction and equivalent seismic static coefficient (Index 3). This stresses the fact that the indexes measure rather different quantities and can hardly be compared between them. Index 2 is dimensional, which means that it should be used with particular care. Index 1 and Index 2 are independent of the design ground acceleration. Therefore, assuming that the buildings must have identical safety, these indexes should be larger with increasing seismicity. On the other hand, Index 3 should be constant in different seismic zones, as it considers the effect of seismicity. Finally, Index 3 format is close to the traditional safety approach adopted for structural design.

\section{Investigation Using Portuguese Churches}

The investigation presented here included the application of the simplified methods to a sample of Portuguese churches, with the following objectives: (a) Validate the hypothesis of an empirical relation of the ancient builders, able to define an expedite preliminary assessment of seismic vulnerability of historical masonry buildings; (b) Validate the hypothesis of an empirical relation between architectural-structural characteristics of 
historical masonry buildings and seismicity; (c) Prioritize further investigations and possible remedial measures for the selected sample; (d) Extrapolate, from the results on the sample, the seismic vulnerability of ancient masonry buildings in Portugal.

The sample is made of fifty-eight churches selected according to the Portuguese seismic zonation [10], see Figure 1, and to the availability of information at the Database of Architectural Heritage from the General Directorate of Buildings and National Monuments, partly available in [11]. Portuguese zonation includes four zones (A to D), being the design ground acceleration for zone A and rock-like soils equal to $0.27 \mathrm{~g}$ for Type 1 spectra (moderate magnitude and close epicenter) and $0.16 \mathrm{~g}$ for Type 2 spectra (large magnitude and far away epicenter). For zones B, C and D, the seismic action is reduced by $70 \%, 50 \%$ and $30 \%$, respectively. The sample includes twenty-five churches for the higher seismicity zone (A) and eleven churches for each lower seismicity zone $(\mathrm{B}, \mathrm{C}$ and $\mathrm{D})$.

The work was organized so that, for each church, an inventory form was filled including the classification, construction date, short description and reported previous seismic damage (if any), see Figure 2. In addition, a structural performance form was also prepared, incorporating the most relevant parameters, see Figure 3.

\subsection{Global Analysis of Results}

For the application of the simplified analysis methods, it was assumed that all the masonry materials were similar, the volumetric weight of masonry was $20 \mathrm{kN} / \mathrm{m}^{3}$, the weight of roofs was equal to $2.0 \mathrm{kN} / \mathrm{m}^{2}$ and the $\beta$ coefficient was equal to 0.22 [10]. Table 1 gives the values of three indexes for the entire sample, see [12] for a complete description. The shaded cells indicate violation of the conditions provided in Section 3, namely

$\gamma_{1, i} \leq 10 \%, \quad \gamma_{2, i} \leq 1.2 \mathrm{MN} / \mathrm{m}^{2}$ and $\gamma_{3, i} \leq 1.0$. For indexes 1 and 2 , the seismicity is taken into account by multiplying the threshold by the seismicity coefficient $\alpha$ according to the zone A, B, C and D, respectively equal to $1.0,0.7,0.5$ and 0.3 .

Index $\gamma_{1}$ indicates a unexpected variation for the churches, because the average values exhibit minor differences according to the seismicity, see Figure 4, contrarily to the expected dependency $\left(\gamma_{1, \mathrm{~A}}>\gamma_{1, \mathrm{~B}}>\gamma_{1, \mathrm{C}}>\right.$ $\left.\gamma_{1, \mathrm{D}}\right)$. On average, the adopted criterion is not violated but, individually, four churches $(16 \%)$ in zone A and three churches $(27 \%)$ in zone B, violate the adopted criterion, see Table 1. As expected, all cases that might require further investigation are due to a deficient earthquake resistance along the transversal direction of the church nave (direction $x)$. 
Index $\gamma_{2}$, although being inversely proportional to the height of the buildings, presents a situation similar to Index 1. Again, the calculated values are independent of the seismic zone, which is partly associated with the fact that the height of the buildings is not decreasing with increasing seismicity, see Figure 5a. It is also interesting to confirm the early statement that vertical loading is mostly due to self-weight of the walls, see Figure $5 \mathrm{~b}$. The fact that not a single building violates the criterion proposed by [7] and adopted here, see Table 1, seems to indicate that the threshold needs revision and is in conflict with Index 1.

Index $\gamma_{3}$, as a direct result from the constant values of indexes 1 and 2 , exhibits increasing values with decreasing seismicity, see Figure 6. On average, index $\gamma_{3}$ is on the verge of violation for the adopted criterion of zone A, but adequate for the other zones. Individually, seventeen churches (68\%) in zone A and one church (9\%) in zone B, violate the adopted criterion. Again, almost all cases that might require further investigation are due to a deficient earthquake resistance along the transversal direction of the church nave (direction $x$ ). Moreover, Index 3 is clearly in conflict with the other two indexes, indicating that a new proposal for criteria violation is needed. As stressed before, a value of zero was adopted for the cohesion, if a value of $0.10 \mathrm{~N} / \mathrm{mm}^{2}$ is adopted for the cohesion all churches fulfill the adopted criterion.

\subsection{Proposal for the Usage of Simplified Indexes}

Index 1 is independent from the height, which is considered a major drawback. Therefore, only Index 2 and 3 are further analyzed. The comparison between $\gamma_{2}$ and $\gamma_{3}$ is equivalent to compare $(1 / h)$ and $(1 / \beta)$, see Eq. (6), or height and seismicity, if cohesion is ignored. These quantities are clearly not comparable and, according, to the results of the present paper seem uncorrelated. In order to take the value of the height $h$ of the building into account, the following approach is suggested:

1. Assume that the criterion for $\gamma_{3}$ must be fulfilled. This results in a minimum value of $\gamma_{3, i \min }$ equal to the unit value. Introducing Eq. (4), it is possible to obtain a minimum ratio of walls as

$$
\gamma_{3, \mathrm{i} \min }=1.0 \Leftrightarrow\left(A_{w i} / A_{w}\right)_{\min } \times \tan \varphi / \beta=1.0 \Leftrightarrow\left(A_{w i} / A_{w}\right)_{\min .}=\beta / \tan \varphi
$$

Introducing this result in Eq. (2), the minimum value of $\gamma_{2, i \text { min }}$ reads

$$
\gamma_{2, i \min }=\left(A_{w i} / A_{w}\right)_{\min } \times 1 /(\gamma \times h)=\beta /(\gamma \times h \times \tan \varphi)
$$


Finally, assuming $\gamma$ equal to $20 \mathrm{kN} / \mathrm{m}^{3}, \tan \varphi$ equal to 0.4 and $\beta$ equal to $0.22 \alpha$, the minimum value of $\gamma_{2, i \text { min }}$ can be simplified to

$$
\gamma_{2, i \min }=27.5 \alpha / \mathrm{h} \quad\left[\mathrm{m}^{2} / \mathrm{MN}\right]
$$

2. Assume that the average value of the height of the buildings in a given seismic zone is correct as a result of the experience of the ancient builders or the earthquake damage, subsequent iterative correction of geometry. For the sample of churches adopted in the present study, the equivalent height of the buildings is shown in Figure $5 \mathrm{~b}$, and reads $8.5,10.4,8.2$ and $8.6 \mathrm{~m}$, respectively for seismic zones A, B, C and D. With these values of average building height, the values obtained for $\gamma_{2, i \text { min_ag }}$ are given in Table 2 . These results indicate that the value proposed in [7] for high seismicity cases seems too low.

The proposed strategy to perform a preliminary screening and to prioritize deeper studies in historical masonry structures in earthquake prone countries is to adopt as criteria simultaneously Index 2 and Index 3 , such as that $\gamma_{2}>\gamma_{2, \text { min_} \alpha \gamma}$ and $\gamma_{3}>1.0$. It is stressed that: (a) the first criterion is different than imposing a maximum height to the building, because both the walls, the height and the seismicity are involved in the inequality; (b) the second criterion only takes into account the height of the building if cohesion is different than zero and, therefore, might provide unreliable results. Application of this strategy to the present sample, leads to the results shown in Table 3, where 10 churches out of the original 58 sample deserve deeper investigations. Nine churches ( $36 \%$ of the sample) are located in a high seismicity zone, which seems to reveal a dangerous situation for the country architectural heritage.

\section{Conclusions}

This paper presents an investigation about the possibility of using simplified methods of analysis and simple indexes as indicators for fast screening and decision to prioritize deeper studies in historical masonry buildings and assess vulnerability to seismic actions. These indexes are based mostly on the in plan dimensions and height of the buildings. The simplified methods indicate that, in Portugal, the average in plan area of earthquake resistant walls and average height are independent of the seismicity. This puzzling feature can be related to the short memory of the ancient builders and the fact that major earthquakes in Portugal have rather long return periods (over 200 years). 
In general, the longitudinal direction of the buildings $(y)$ exhibits much lower vulnerability than the transversal direction $(x)$. For the buildings located in the higher seismicity zone (design ground acceleration of $0.27 \mathrm{~g}), 36 \%$ of sample requires remedial measures or, at least, deeper investigations. In medium and low seismicity zones, only one building ( $3 \%$ of the sample) was found vulnerable.

A proposal for the usage of simplified methods was made, taking into consideration the in plan area of the building, its height and seismicity, with the simultaneous verification of two indexes, one related to ratio of in plan area and weight $\left(\gamma_{2}\right)$, and another related to the maximum base shear force $\left(\gamma_{3}\right)$, such that $\gamma_{2}>\gamma_{2}$, min_ag and $\gamma_{3}>1.0$. Here, $\gamma_{2}$, min_ag is a tabulated value function of the local experience of builders and seismicity, ranging between 0.95 and $3.25 \mathrm{~m}^{2} / \mathrm{MN}$ for the Portuguese reality.

\section{Acknowledgements}

The authors gratefully acknowledge the support of the European-Indian Economic Cross Cultural Programme, under contract ALA/95/23/2003/077-122, “Improving the Seismic Resistance of Cultural Heritage Buildings". The work was also partially supported by project SAPIENS 33935-99 funded by the Portuguese Science and Technology Foundation (FCT).

\section{References}

1. G.N.D.T., Seismic damage and vulnerability of the churches in Umbria (in Italian), CD-Rom, Presidency from the Ministry Council 1998.

2. Barbat, A.H., Yépez, F., Canas, J.A, Damage scenarios simulation for seismic risk assessment in urban zones, Earthquake Spectra 1996; 12(3): 371-394.

3 Langa, K., Bachmanna, H., On the seismic vulnerability of existing buildings: A case study of the city of Basel, Earthquake Spectra 2004; 20(1): 43-66.

4 . Lourenço, P.B., Computations of historical masonry constructions, Progress in Structural Engineering and Materials 2002; 4(3): 301-319.

5. ICOMOS, Recommendations for the analysis, conservation and structural restoration of architectural heritage, 2001.

6. Giuffrè, A., Seismic damage in historic town centers and attenuation criteria. Annali di Geofisica 1995; 38(56): 837-843. 
7. Meli, R., Structural engineering of historical buildings (in Spanish). Mexico-City : Fundación ICA, 1998.

8. CEN, Eurocode 8: Design of structures for earthquake resistance, prEN 1998-1. Brussels : CEN, 2003.

9. CEN, Eurocode 6: Design of masonry structures, prEN 1996-1. Brussels : CEN, 2003.

10. M.H.O.P.T., Safety and action code for building and bridges structures (in Portuguese), Legal-Decree no. 235/83. Lisbon : INCM, 1983.

11. DGEMN, Architectural heritage inventory. Lisbon : Direcção Geral de Edifícios e Monumentos Nacionais. Available from www.monumentos.pt.

12. Roque, J.A., Strengthening and structural rehabilitation of ancient masonry walls (in Portuguese), MSc Thesis, Guimarães : University of Minho, 2002. Also available from www.civil.uminho.pt/masonry. 


\section{List of Tables}

Table 1 - Indexes for the full sample (shaded values represent violation of the criteria adopted in Section 3)

Table 2 - Recommended values for the minimum value of Index 2

Table 3 - Indexes for the full sample (shaded indexes represent violation of the proposed criteria and shaded church indicates the need of a deeper study) 


\section{List of Figures}

Figure 1 - Seismic zonation of Portugal [10] and location of the churches (zone A is high seismicity and zone D is low seismicity)

Figure 2 - Typical inventory form for the churches (non-structural aspects)

Figure 3 - Typical structural performance form for the churches

Figure 4 - Average results for index g1, according to orthogonal directions (line indicates the threshold)

Figure 5 - Index $\gamma_{2}$ : (a) average results according to orthogonal directions (line indicates the threshold);

(b) average height(s) of the buildings, being the equivalent height defined as $h_{\text {equiv }}=G /\left(A_{w} \times \gamma\right)$

Figure 6 - Average results for index g3, according to orthogonal directions (line indicates the threshold) 
Table 1 - Indexes for the full sample (shaded values represent violation of the criteria adopted in Section 3)

\begin{tabular}{|c|c|c|c|c|c|c|c|c|}
\hline \multirow[b]{2}{*}{ Zone } & \multirow[b]{2}{*}{ Designation of church } & \multirow[b]{2}{*}{ Location } & \multicolumn{2}{|c|}{ Î́ndex 1} & \multicolumn{2}{|c|}{ Índex 2} & \multicolumn{2}{|c|}{ Index 3} \\
\hline & & & $\gamma_{1 x}$ & $\gamma_{1 y}$ & $\gamma_{2 x}$ & $\gamma_{2 y}$ & $\gamma_{3 x}$ & $\gamma_{3 y}$ \\
\hline A1 & Igreja de Santa Cruz - Almodôvar & Beja & 0.14 & 0.18 & 3.87 & 5.07 & 1.00 & 1.31 \\
\hline $\mathrm{A} 2$ & Igreja de Santo Amaro & Beja & 0.11 & 0.17 & 3.49 & 5.34 & 0.93 & 1.42 \\
\hline A3 & Igreja da Misericórdia de Beja & Beja & 0.10 & 0.11 & 4.02 & 4.18 & 1.15 & 1.20 \\
\hline A4 & Igreja da Misericórdia das Entradas & Castro Verde & 0.16 & 0.31 & 3.32 & 6.48 & 0.74 & 1.44 \\
\hline$\overline{\mathrm{A} 5}$ & Igreja Matriz de Mértola & Mértola & 0.12 & 0.14 & 3.30 & 3.96 & 1.00 & 1.17 \\
\hline A6 & Igreja Matriz de Entradas & Castro Verde & 0.11 & 0.24 & 2.15 & 4.78 & 0.76 & 1.68 \\
\hline A7 & Igreja Matriz de Vila do Bispo & V. Bispo & 0.15 & 0.15 & 4.62 & 4.69 & 0.96 & 0.97 \\
\hline A8 & Igreja da Luz - Capela Mor & Lagos & 0.12 & 0.14 & 3.99 & 4.83 & 0.95 & 1.15 \\
\hline A9 & Igreja Matriz de Loulé & Loulé & 0.17 & 0.15 & 3.59 & 3.16 & 1.32 & 1.16 \\
\hline A10 & Sé de Silves & Silves & 0.12 & 0.18 & 2.02 & 3.00 & 0.94 & 1.40 \\
\hline A11 & Igreja Matriz & Alcochete & 0.13 & 0.16 & 3.97 & 4.97 & 0.94 & 1.17 \\
\hline A12 & Igreja do Antigo Mosteiro de Jesus & Setúbal & 0.11 & 0.24 & 1.43 & 3.02 & 0.67 & 1.42 \\
\hline A13 & Igreja Matriz S. Salvador & Sines & 0.12 & 0.15 & 2.78 & 3.68 & 0.92 & 1.22 \\
\hline A14 & Igreja de S. Lourenço & V.N. Azeitão & 0.09 & 0.17 & 2.85 & 5.59 & 0.79 & 1.55 \\
\hline A15 & Igreja de Nossa Senhora da Graça & Barreiro & 0.10 & 0.14 & 3.98 & 5.43 & 0.92 & 1.26 \\
\hline A16 & Igreja de São Quintino & Sobral & 0.11 & 0.16 & 2.65 & 3.98 & 0.86 & 1.29 \\
\hline A17 & Igreja da Cheleiros & Mafra & 0.16 & 0.14 & 4.26 & 3.90 & 0.95 & 0.87 \\
\hline A18 & Igreja de Santa Maria & Sintra & 0.12 & 0.19 & 3.06 & 4.74 & 1.00 & 1.52 \\
\hline A19 & Igreja de Santo André & Mafra & 0.13 & 0.19 & 3.67 & 5.38 & 1.00 & 1.46 \\
\hline A20 & Igreja Matriz da Lourinhã & Lourinhã & 0.11 & 0.19 & 3.11 & 5.48 & 0.89 & 1.57 \\
\hline A21 & Igreja Matriz de Loures & Loures & 0.09 & 0.20 & 1.45 & 3.38 & 0.63 & 1.47 \\
\hline A22 & Igreja Paroquial de S. Cristóvão & Lisboa & 0.14 & 0.17 & 3.30 & 4.00 & 1.27 & 1.54 \\
\hline A23 & Igreja de São Domingos & Lisboa & 0.19 & 0.22 & 3.84 & 4.35 & 1.61 & 1.83 \\
\hline A24 & Igreja da Terrugem & Sintra & 0.13 & 0.17 & 4.73 & 6.03 & 1.04 & 1.32 \\
\hline $\mathrm{A} 25$ & Igreja Matriz de Arruda dos Vinhos & A. dos Vinhos & 0.12 & 0.14 & 3.52 & 4.05 & 1.14 & 1.31 \\
\hline $\mathrm{B} 1$ & Igreja de Santa Clara & Santarém & 0.07 & 0.12 & 1.53 & 2.72 & 1.08 & 1.92 \\
\hline $\mathrm{B} 2$ & Igreja Matriz da Golegã & Golegã & 0.08 & 0.13 & 2.34 & 3.66 & 1.34 & 2.10 \\
\hline B3 & Igreja Matriz de Arronches & Portalegre & 0.09 & 0.14 & 2.23 & 3.37 & 1.22 & 1.84 \\
\hline $\mathrm{B} 4$ & Igreja Matriz da Redinha & Pombal & 0.11 & 0.17 & 3.18 & 5.01 & 1.07 & 1.68 \\
\hline $\mathrm{B} 5$ & Igreja Matriz de S. João Baptista & Moura & 0.09 & 0.13 & 1.86 & 2.86 & 1.29 & 1.99 \\
\hline B6 & Igreja de S. Pedro & Leiria & 0.06 & 0.20 & 1.68 & 5.26 & 0.70 & 2.19 \\
\hline B7 & Igreja Matriz da Batalha & Batalha & 0.11 & 0.15 & 2.96 & 4.01 & 1.28 & 1.74 \\
\hline $\mathrm{B} 8$ & Igreja de Sta. Maria dos Olivais & Tomar & 0.07 & 0.10 & 2.75 & 4.01 & 1.17 & 1.71 \\
\hline B9 & Igreja da Atalaia & Santarém & 0.18 & 0.21 & 5.32 & 6.37 & 1.88 & 2.25 \\
\hline $\mathrm{B} 10$ & Igreja de Santa Cruz & Santarém & 0.12 & 0.14 & 2.52 & 2.83 & 1.30 & 1.46 \\
\hline $\mathrm{B} 11$ & Sé de Évora & Évora & 0.09 & 0.15 & 1.17 & 1.94 & 1.09 & 1.82 \\
\hline C1 & Igreja de S. Tiago de Coimbra & Coimbra & 0.09 & 0.19 & 1.72 & 3.60 & 1.17 & 2.45 \\
\hline $\mathrm{C} 2$ & Igreja Matriz de Vouzela & Vouzela & 0.11 & 0.21 & 2.51 & 4.68 & 1.43 & 2.66 \\
\hline C3 & Igreja de Nossa Senhora da Fresta & Trancoso & 0.11 & 0.22 & 2.64 & 5.55 & 1.29 & 2.70 \\
\hline $\mathrm{C} 4$ & Igreja de São Pedro de Arganil & Arganil & 0.08 & 0.14 & 4.50 & 7.69 & 1.55 & 2.64 \\
\hline C5 & Sé velha & Coimbra & 0.15 & 0.20 & 1.64 & 2.07 & 1.99 & 2.52 \\
\hline C6 & Igreja Matriz da Lourosa & Oliv. Hospital & 0.09 & 0.15 & 4.17 & 7.11 & 1.54 & 2.63 \\
\hline C7 & Igreja da Tocha & Cantanhede & 0.10 & 0.18 & 1.62 & 2.87 & 1.32 & 2.35 \\
\hline $\mathrm{C} 8$ & Igreja Par. de Figueiró dos Vinhos & Leiria & 0.10 & 0.11 & 2.92 & 3.09 & 1.99 & 2.10 \\
\hline C9 & Igreja de S. João deTarouca & Viseu & 0.07 & 0.15 & 3.40 & 7.10 & 1.31 & 2.75 \\
\hline $\mathrm{C} 10$ & Igreja da Misericórdia do Sabugal & Guarda & 0.10 & 0.15 & 3.17 & 4.81 & 1.63 & 2.46 \\
\hline C11 & Igreja de S. Miguel de Urrô & Arouca & 0.10 & 0.22 & 2.83 & 6.03 & 1.37 & 2.92 \\
\hline D1 & Igreja da Misericórdia & Freixo E. Cinta & 0.15 & 0.11 & 2.52 & 1.89 & 3.63 & 2.72 \\
\hline $\mathrm{D} 2$ & Igreja de Algosinho & Mogadouro & 0.14 & 0.21 & 4.52 & 6.45 & 3.02 & 4.31 \\
\hline D3 & Igreja do Tabuado & Marco & 0.15 & 0.17 & 2.72 & 3.07 & 2.55 & 2.87 \\
\hline D4 & Igreja Matriz de Armamar & Armamar & 0.13 & 0.18 & 2.96 & 4.18 & 3.00 & 4.23 \\
\hline D5 & Igreja de N. Sra da Orada & Melgaço & 0.12 & 0.23 & 2.29 & 4.53 & 1.95 & 3.86 \\
\hline D6 & Igreja de S. Miguel do Castelo & Guimarães & 0.11 & 0.24 & 3.02 & 6.58 & 2.20 & 4.79 \\
\hline D7 & Igreja de Almacave & Lamego & 0.15 & 0.18 & 2.86 & 3.44 & 3.13 & 3.75 \\
\hline D8 & Igreja de S. Martinho de Cedofeita & Porto & 0.24 & 0.28 & 2.77 & 3.24 & 3.69 & 4.32 \\
\hline D9 & Igreja de Santo Cristo de Outeiro & Vimioso & 0.15 & 0.17 & 2.03 & 2.25 & 3.64 & 4.04 \\
\hline D10 & Igreja de N. Sra da Azinheira & Chaves & 0.10 & 0.25 & 2.83 & 7.25 & 1.91 & 4.91 \\
\hline D11 & Igreja de S. Fins de Friestas & Viana & 0.11 & 0.24 & 3.07 & 6.90 & 2.84 & 6.38 \\
\hline
\end{tabular}


Table 2 - Recommended values for the minimum value of Index 2

\begin{tabular}{|c|c|c|}
\hline Seismic Zone & $\beta$ & $\gamma_{2, \min a g}\left(\mathrm{~m}^{2} / \mathrm{MN}\right)$ \\
\hline $\mathrm{A}$ & 0.22 & 3.25 \\
\hline $\mathrm{B}$ & 0.15 & 1.85 \\
\hline $\mathrm{C}$ & 0.11 & 1.70 \\
\hline $\mathrm{D}$ & 0.07 & 0.96 \\
\hline
\end{tabular}


Table 3 - Indexes for the full sample (shaded indexes represent violation of the proposed criteria and shaded church indicates the need of a deeper study)

\begin{tabular}{|c|c|c|c|c|c|c|}
\hline & & & & & & \\
\hline & & & 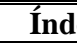 & $\overline{x 2}$ & & $\mathbf{x} 3$ \\
\hline Zone & Designation of church & Location & $\gamma_{2 \mathrm{x}}$ & $\gamma_{2 y}$ & $\gamma_{3 x}$ & $\gamma_{3 y}$ \\
\hline A1 & Igreja de Santa Cruz - Almodôvar & Beja & 3.87 & 5.07 & 1.00 & 1.31 \\
\hline A2 & Igreja de Santo Amaro & Beja & 3.49 & 5.34 & 0.93 & 1.42 \\
\hline A4 & Igreja da Misericórdia das Entradas & Castro Verde & 3.32 & 6.48 & 0.74 & 1.44 \\
\hline A5 & Igreja Matriz de Mértola & Mértola & 3.30 & 3.96 & 1.00 & 1.17 \\
\hline A6 & Igreja Matriz de Entradas & Castro Verde & 2.15 & 4.78 & 0.76 & 1.68 \\
\hline A7 & Igreja Matriz de Vila do Bispo & V. Bispo & 4.62 & 4.69 & 0.96 & 0.97 \\
\hline A8 & Igreja da Luz - Capela Mor & Lagos & 3.99 & 4.83 & 0.95 & 1.15 \\
\hline A10 & Sé de Silves & Silves & 2.02 & 3.00 & 0.94 & 1.40 \\
\hline A11 & Igreja Matriz & Alcochete & 3.97 & 4.97 & 0.94 & 1.17 \\
\hline A12 & Igreja do Antigo Mosteiro de Jesus & Setúbal & 1.43 & 3.02 & 0.67 & 1.42 \\
\hline A13 & Igreja Matriz S. Salvador & Sines & 2.78 & 3.68 & 0.92 & 1.22 \\
\hline A14 & Igreja de S. Lourenço & V.N. Azeitão & 2.85 & 5.59 & 0.79 & 1.55 \\
\hline A15 & Igreja de Nossa Senhora da Graça & Barreiro & 3.98 & 5.43 & 0.92 & 1.26 \\
\hline A16 & Igreja de São Quintino & Sobral & 2.65 & 3.98 & 0.86 & 1.29 \\
\hline A17 & Igreja da Cheleiros & Mafra & 4.26 & 3.90 & 0.95 & 0.87 \\
\hline A18 & Igreja de Santa Maria & Sintra & 3.06 & 4.74 & 1.00 & 1.52 \\
\hline A19 & Igreja de Santo André & Mafra & 3.67 & 5.38 & 1.00 & 1.46 \\
\hline A20 & Igreja Matriz da Lourinhã & Lourinhã & 3.11 & 5.48 & 0.89 & 1.57 \\
\hline A21 & Igreja Matriz de Loures & Loures & 1.45 & 3.38 & 0.63 & 1.47 \\
\hline $\mathrm{B} 1$ & Igreja de Santa Clara & Santarém & 1.53 & 2.72 & 1.08 & 1.92 \\
\hline B6 & Igreja de S. Pedro & Leiria & 1.68 & 5.26 & 0.70 & 2.19 \\
\hline B11 & Sé de Évora & Évora & 1.17 & 1.94 & 1.09 & 1.82 \\
\hline
\end{tabular}




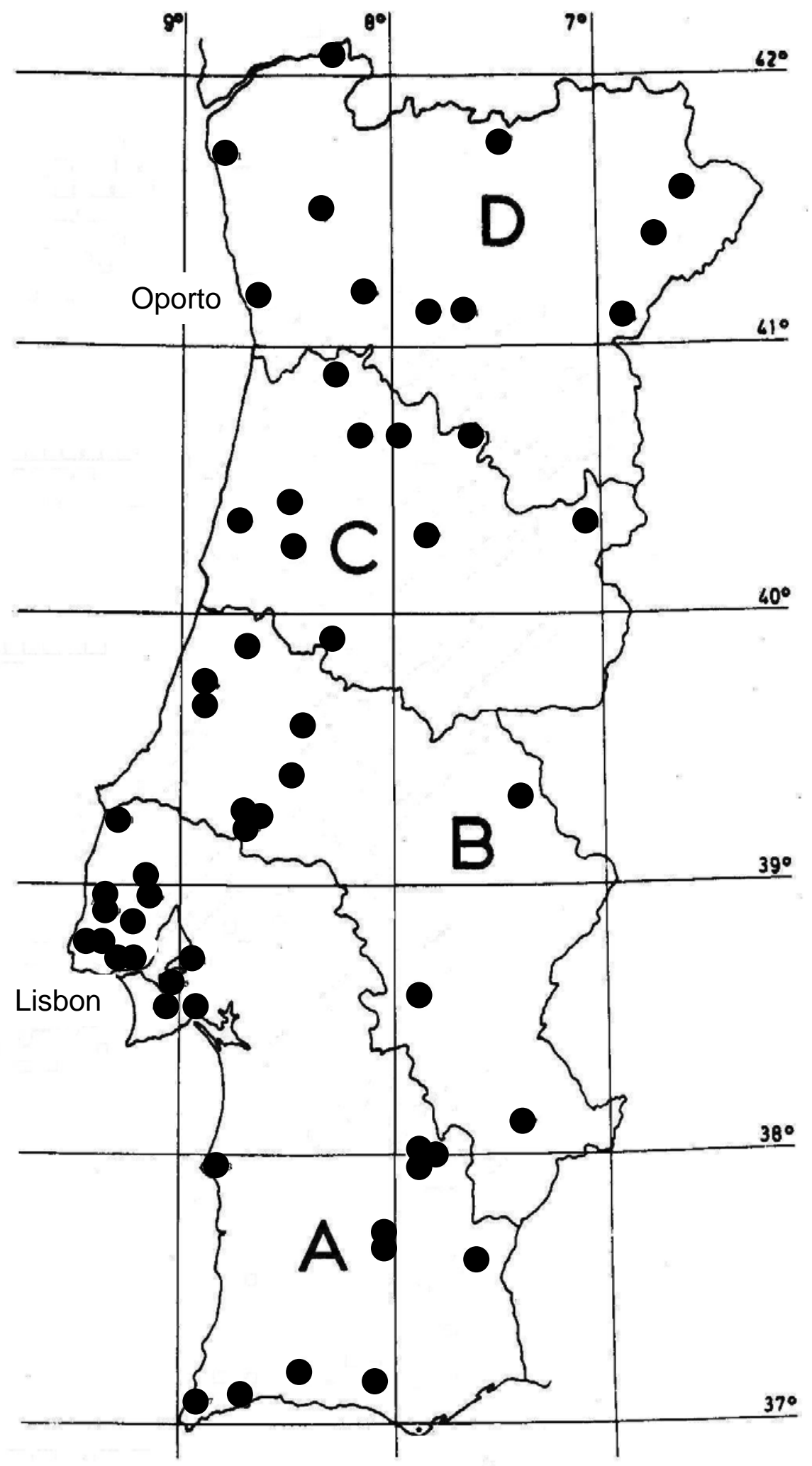

Figure 1 - Seismic zonation of Portugal [10] and location of the churches (zone A is high seismicity and zone D is low seismicity) 
PT1-Church of Santa Cruz, Almodôvar-Beja, Portugal

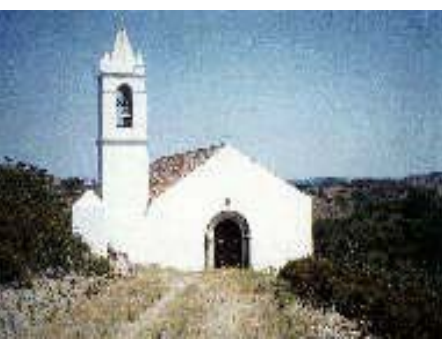

(a)

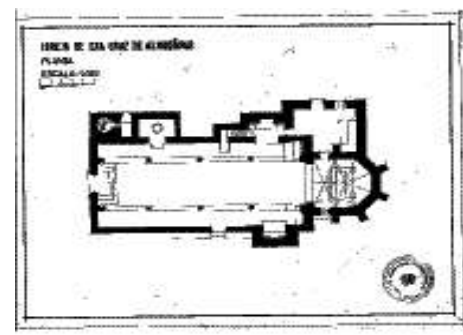

(b)

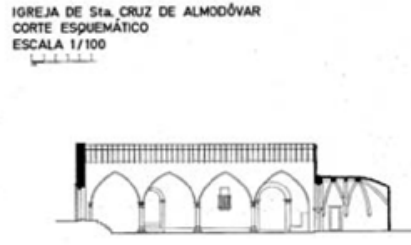

(c)

Geometry: (a) photo; (b) plan; (c) cross-section

[Source: DGEMN - General Directorate for Monuments and Sites]

National Classification: Construction of Public Interest (IIP)

Construction period: $16^{\text {th }}, 17^{\text {th }}, 18^{\text {th }}$ (construction supposedly initiated in 1501 , with possible inauguration in 1740 according to the date engraved in the doorsill of the sacristy door)

\section{Description:}

Longitudinal plan with rectangular nave with small side-chapels, quadrilateral bell-tower at the left, polygonal apse and rectangular sacristy at the left. Stepped volumes with a distinct double-sloping roof, over the church, and a prismatic spire, over the bell-tower. Main façade in a single gable wall, with a single opening: a portal with three semicircular archivolts of torso colonettes. Side bell-tower with two levels, with window openings in the upper part with semicircular archivolt. Back façade highlighted by the lower volume of the chancel, polygonal and with stepped buttresses.

Interior with three naves, of four spans, separated by pointed arches and ashlar columns. The main nave, three times large than the side naves, has wood lath-work ceilings. Triumphal arch over the columns. Chancel with roof in star ribbed vault, supported in brackets.

Load-bearing walls in rendered stone masonry. Double-sloping roof with a timber structure. Since 1962, DGEMN has carried out minor conservation works.

Previous Seismic Damage:

It is likely that the 1755 earthquake hit the structure but any possible damage is not documented, due to the fact that Almodôvar is an isolated rural settlement, with few inhabitants and low regional importance.

Figure 2 - Typical inventory form for the churches (non-structural aspects) 
PT1- Church of Santa Cruz. Almodôvar-Beja. Portugal

Simplified Methods:

\begin{tabular}{|c|c|c|c|c|c|}
\hline \multicolumn{2}{|c|}{ In- plan area ratio } & \multicolumn{2}{c|}{ Area to weight ratio } & \multicolumn{2}{c|}{ Base shear ratio } \\
\hline$x$ direction & $y$ direction & $x$ direction & $y$ direction & $x$ direction & $y$ direction \\
\hline 0.14 & 0.18 & 3.87 & 5.07 & 1.0 & 1.31 \\
\hline
\end{tabular}

Other Key Structural Features:

\section{VAULT IN MAIN SPACE}

$\square$ Yes $\mathbf{x}$ No. Specify: Only in the ceiling of the chancel.

\section{TYPE}

\begin{tabular}{|c|c|c|c|c|c|c|c|c|c|c|}
\hline & & Crossed & & med & $\mathbf{x}$ & \multicolumn{5}{|c|}{ Other. Specify: Star ribbed vault } \\
\hline \multicolumn{11}{|c|}{ GEOMETRICAL DATA (meters) } \\
\hline 5.0 & & 3.0 & Rise $r$ & 0.22 & & nickness at key $t$ & $1 / 1.7$ & $r / s(-)$ & $1 / 15$ & $t / s(-)$ \\
\hline
\end{tabular}

DATA FOR COLUMNS IN MAIN SPACE (meters and kN)

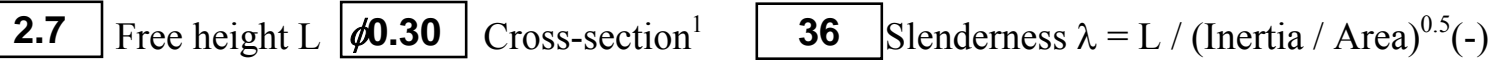

150 Vertical load $\mathbf{1 6 1 5}$ Euler critical load $\quad \mathbf{1 / 9}$ Thickness / height. if applicable (-)

\section{DATA FOR PERIMETER WALLS IN MAIN SPACE (meters)}

5.20 Maximum free height 0.55 Equivalent thickness ${ }^{2} \quad 1 / 9.5$ Thickness / height (-)

\section{MAGNITUDE OF SEISMIC LOADING $\left(\mathrm{m} / \mathrm{s}^{2}\right)$}

2.7 PGA for Type $1^{3} \quad \mathbf{1 . 6}$ PGA for Type 2

${ }^{1} 0.50 \times 1.25$ or $\phi 0.90$ or $\mathrm{I}_{\mathrm{x}} 0.55$ (for other shapes, lowest inertia)

${ }^{2}$ Takes into account buttresses and openings to calculate the equivalent thickness

${ }^{3}$ Type 1 (moderate magnitude and close epicenter) and Type 2 (large magnitude and far away epicenter)

Figure 3 - Typical structural performance form for the churches 


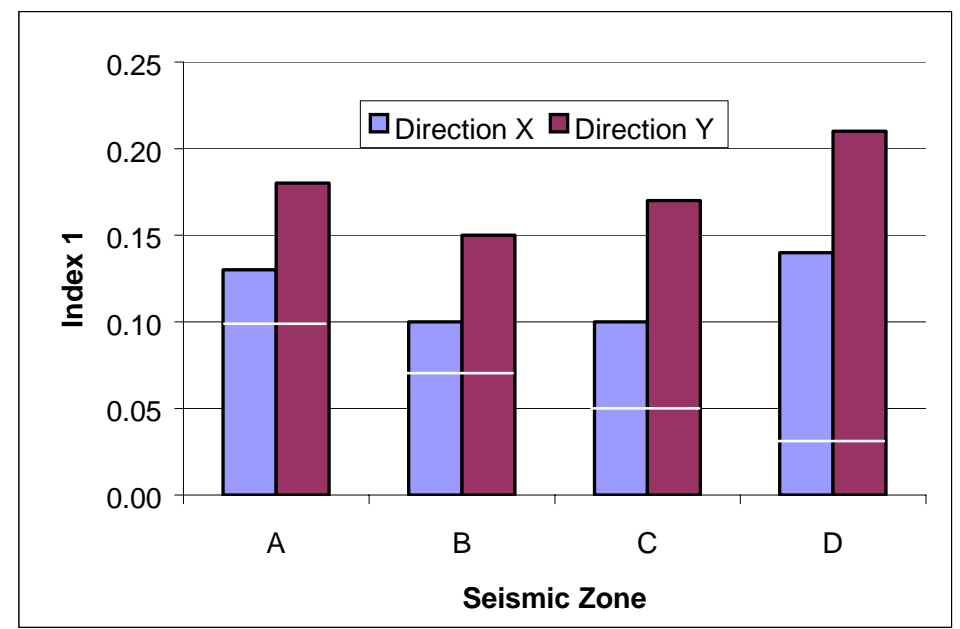

Figure 4 - Average results for index $\gamma_{1}$, according to orthogonal directions (line indicates the threshold) 


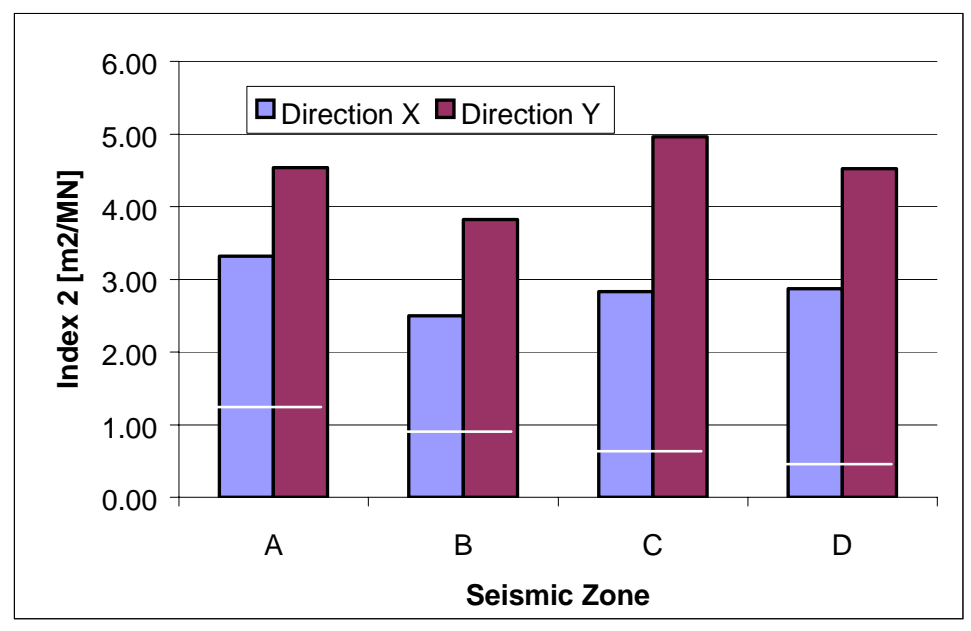

(a)

Figure 5 - Index $\gamma_{2}$ : (a) average results according to orthogonal directions (line indicates the threshold);

(b) average height of the buildings defined as $h_{\text {equiv }}=G /\left(A_{w} \times \gamma\right)$ 


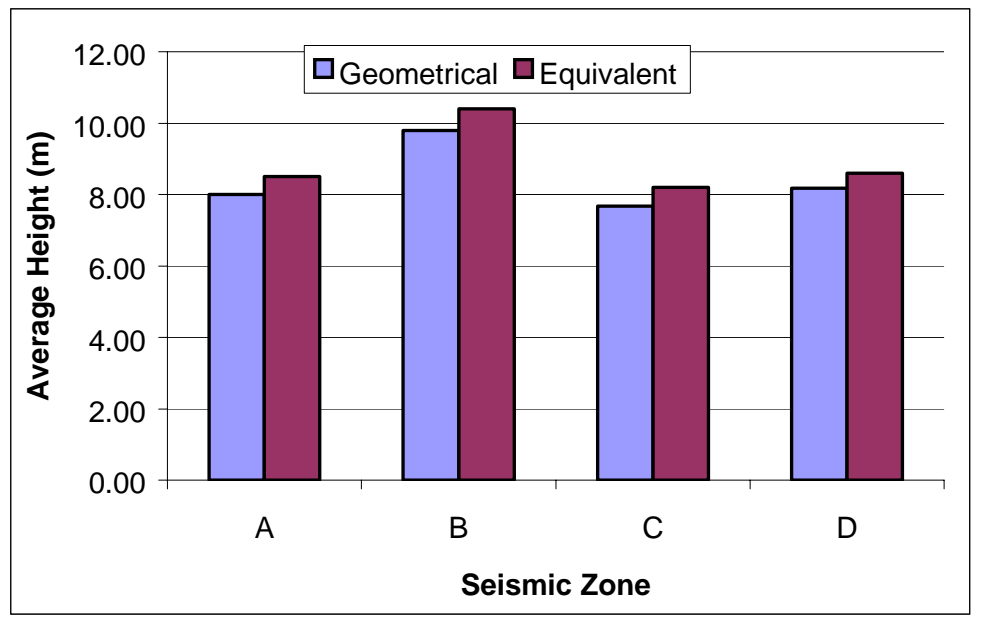

(b)

Figure 5 - Index $\gamma_{2}$ : (a) average results according to orthogonal directions (line indicates the threshold);

(b) average height(s) of the buildings, being the equivalent height defined as $h_{\text {equiv }}=G /\left(A_{w} \times \gamma\right)$ 


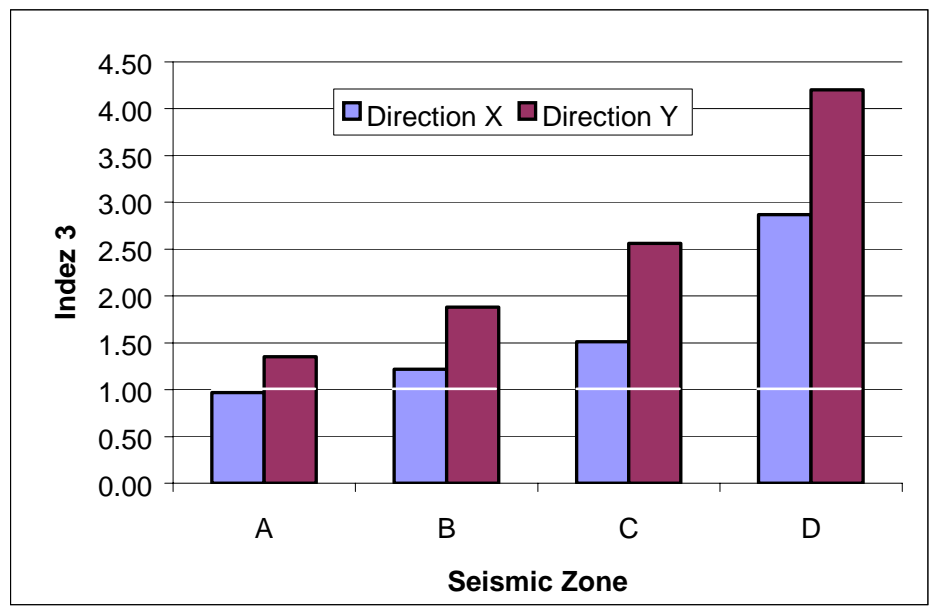

Figure 6 - Average results for index $\gamma_{3}$, according to orthogonal directions (line indicates the threshold) 